\title{
The Concept of Private-Administration Contracts in Settling Problems in Government Goods/Services Procurement Contracts
}

\author{
Solechan, Kadek Cahya Susila Wibawa* and Ajik Sujoko
}

Faculty of Law, Diponegoro University, Semarang, Indonesia

\begin{abstract}
Contracts for the procurement of government goods/services are the realm of private law that implements pure private contracts. A legal relationship in a private contract, especially in a contract settlement, is a relationship between the settlement of the rights and obligations of the parties. This study describes the settlement of government goods/service procurement contracts that require a legal basis both in principle and theory. By using the conceptual analysis method, the findings indicate an inconsistency in solving a legal problem in a government procurement contract, where private legal issues are resolved through administrative law. Theoretically, this study contributes to the resolution of this problem, there are intersections between two legal aspects, namely private law and administrative law. In practical terms, this study encourages the development of government goods/service procurement contract problem-solving practices to adopt the contract problem-solving method starting to use administrative law.
\end{abstract}

Keywords: Contractual issues, Private-Administration Contracts, Procurement, Administrative Court, Dispute Resolution.

\section{INTRODUCTION}

Contracts for the procurement of goods/services of the government are part of the implementation process in procurement. Although the procurement process is started from the identification, requirements, to the handover of the work (Government of the Republic of Indonesia, 2018). However, many legal issues arise in procurement, especially related to contracts for the procurement of goods/services of the government. Seven dispute problems of contracts for the procurement of goods/services of the government that were resolved through Government Goods/Services Procurement Policy Institute (LKPP) in 2018 include termination of contract/default of $20.23 \%$, contract change of $19.24 \%$, a blacklist of $14.30 \%$, down payment and payment for work achievement of $14.11 \%$, sanctions of $10.96 \%$, force majeure/ compensation event of $10.96 \%$ and price adjustment of $10.17 \%$ (Zenju, 2004).

Resolving legal issues in contracts for the procurement of goods/services of the government requires a proper legal basis, principle, and theory, both through litigation and non-litigation. Legal procurement of goods and services of the government is included in administrative law (Lubis \& Kalo, 2013). In its establishment, the legal aspect refers to the theory of merging, starting from the preparatory stage, the media designation, the signing of the contract, to the termination of the contract, aspects of the

*Address correspondence to this author at the Faculty of Law, Diponegoro University, Semarang, Jl. Prof. Soedarto, Tembalang, Semarang 50275, Central Java, Indonesia; E-mail: kcswibawa.undip@gmail.com administrative law of the state are not included in the scope the procurement of goods/services of the government (Sujoko, 2019).

Opplosing theory as a guideline in examining whether or not a State Administration (TUN) officials' legal actions merge as an act in a civil relationship is the final reach of the TUN's decision issued to produce a civil law act, including to prepare or settle a civil law act (Pedju, 2017). Referring to the implementation of the theory of merging, then the legal aspects of contracts for the procurement of goods/services of the government are in the realm of private law. In its development, the completion of contracts for the procurement of goods/services of the government is not always completed using civil aspects only. For example, the case of completion of work that has been done by the provider and has not been paid but there is/there is no contract. The settlement of such cases is usually done by an audit process, followed by the making of a debt contract, then it is budgeted to pay the work (Mudjisantosa, 2019). This kind of settlement process is a flexibility of the existence of administrative improvements in Law Number 30 of 2014 concerning Government Administration. Another example of settlement is related to sanctions due to provisions in the contract such as blacklist sanctions. When the provider requests the revocation of the blacklist, then the revocation shall be submitted to State Administration Court (Mudjisantosa, 2019).

Based on the explanation above, it proves that the completion of the contracts for the procurement of goods/services of the government is not completely solved by implementing private law but also 
administrative law. Because of this development, according to the authors, there is an area of intersection between administrative law and private law in the contracts for the procurement of goods/services of the government as shown in Figure 1 (Sujoko, 2020).

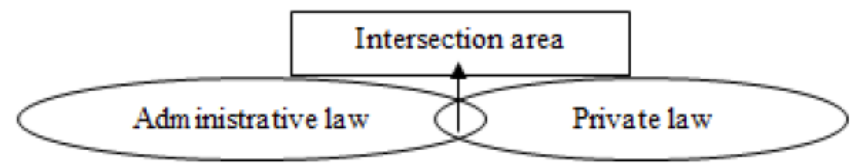

Figure 1: Intersection area of administrative law and private law in contracts for the procurement of goods/services of the government.

Regarding the intersection area of administrative and private law, the authors propose the concept of private-administration contracts.

\section{RESEARCH METHOD}

The methodology is a scientific discipline that pertains to defining and systematizing methods, that is, appropriate ways of discerning the subject of investigation (Jovanovic, 2019). Using the conceptual analysis method, this paper develops new concepts in the intersection between administrative law and private law. These new concepts in resolving contract issues for the procurement of goods/services of the government are a comparison of administrative contracts and private contracts.

\section{RESULT AND DISCUSSION}

\subsection{The Administrative Contracts and the Privat Contracts}

The government commonly makes a draft of contracts before the tender process is performed. The provider position is faced with a take it or leave it situation (Simamora, 2009). When the draft of the contract is accepted in the tender process, the terms and conditions in the contract will apply and be binding when the draft of the contract is signed. Regarding the stages, there are three stages in the contract, including; pre-contractual, contractual, and postcontractual (Faisal, 2018). The authors divide the contract stages into 4 stages, including pre-contractual, contractual, contractual implementation, and postcontractual implementation.

Contractualization by the government is performed in its capacity as a private law subject (civil actor) and is made possible because of the principle of freedom of contract. Although the contract formed is classified as a private contract and not an administrative contract, in a commercial contract by the government, there are the principles and norms of public law, along with the principles and norms of private law as the implication of the government's position as the subject of public law (public actors) that are bound (Simamora, 2009).

Administrative contracts are contracts where one of the parties is a public person (Seif, 2011). They are defined as the contracts concluded on the grounds of the will consent which interferes between an authority of public administration or a person authorized by it and a private person, submitted to the administrative law policy (Gamenţ-Antoniu \& Zaharie, 2010). They are convention concluded between a public authority and a private person, a will consent submitted to a special judicial policy of administrative law, a convention that has a specific character due to the parties, object, applicable principles, conclusion, enforcement, ceasing, clauses, and their solving (Gament-Antoniu \& Zaharie, 2010).

For a contract to be considered as an "administrative" one, it must fulfill the following conditions (Seif, 2011):

a. One of the parties there must be a public authority.

b. The administrative judicial authorities must have jurisdiction to look into such contracts.

c. It must be related to public service or be classified by the law as an administrative contract.

d. It must include an "onerous" clause or condition from the public law.

e. It is important to distinguish between an administrative contract and a civil contract in terms of judicial competence and the applicable law.

The administrative contract is one type of contract made by the French Government. Besides the common private contracts, special rules apply namely administrative law. Consequently, this type of contract becomes the jurisdiction of administrative justice. Meanwhile, ordinary private contracts apply the rule of private law and consequently, it becomes the jurisdiction of general justice (Simamora, 2009). Ordinary private contracts are based on the principle of 
freedom of contract. As a universal principle rooted in the understanding of the law, the principle of freedom of contract arises along with the rise of the classical economic notion that glorifies laissez-faire or free competition (Hernoko, 2010). This principle of freedom of contract is recognized in legal agreements in Indonesia (Jamilah, 2012).

According to the general view of the Academic Text Formulation Team of the Constitution Plan on BPHN Contract Law of Indonesian Ministry of Law and Human Rights of 2013 about the general principles of treaty law as seen from the perspective of the basic values of Pancasila is that the principle of freedom of contract which forms the basis for forming agreements and implementing agreements, as seen from the perspective of Pancasila, must be understood as limited freedom. It means that the freedom of parties to agree on the content, form, requirements, etc. of their agreement must be controlled by the principle of equality, respect for differences in the position and interests of each party and third parties (individuals or communities), and by moral values possessed due to human vertical responsibility to the God (honesty, good faith, openness). Agreements made and/or implemented in violation of those principles and values may be deemed to lose their sanctity (Hardjowahono, 2013).

\subsection{Concept of Private-Administration Contracts}

The concept of Private-Administration Contracts is a concept of private contracts in the field of administrative law because there is a relationship between them. The concept of Private-Administration Contracts is in the area of intersection of administrative law and civil law in the contract for Government procurement of goods and services as shown in Figure 2 below:
Government Procurement of goods and services is based on administrative regulations (Sujoko, 2020). Government actions that cause legal consequences can consist of aspects of civil law (civil administration) and aspects of public law. According to Superman \&Atmasasmita (2014 concerning PBJP contracts, even though the legal relationship formed between the government and its partners is a contractual relationship, it contains not only private law, but also public law. If in a commercial contract the parties have full freedom in regulating legal relations or regulating their contractual obligations, then that freedom does not fully apply in a procurement contract by the government because this contract applies a special legal regime. The relationship between state administration and civil law occurs if, during, or at the time of the adoption or appointment of civil law rules becomes the rules of State Administrative law. The State Administration Agency performs acts that are controlled by civil law, a case which is controlled by civil law and administrative law makes the case is settled based on the provisions of the State administrative law (Febrianti 2019). From the matter of a special legal regime based on Suparman \& Atmasasmita's (2014) framework, the method of solution using litigation in the issue of Government procurement of goods and service contracts is carried out specifically, e.g. establishing Special Courts. The reason for the existence of Special Courts in the field of Government procurement of goods and services is applicable today and can accommodate the need for solving problems related to Government procurement of goods and services contracts through litigation. The concept of Special Courts in the field of Government procurement of goods and services according to the authors is to solve administrative, legal, and technical issues related to PBJP issues since pre-contract, contract signing, contract implementation, and postcontract implementation with cheap costs and fast way.

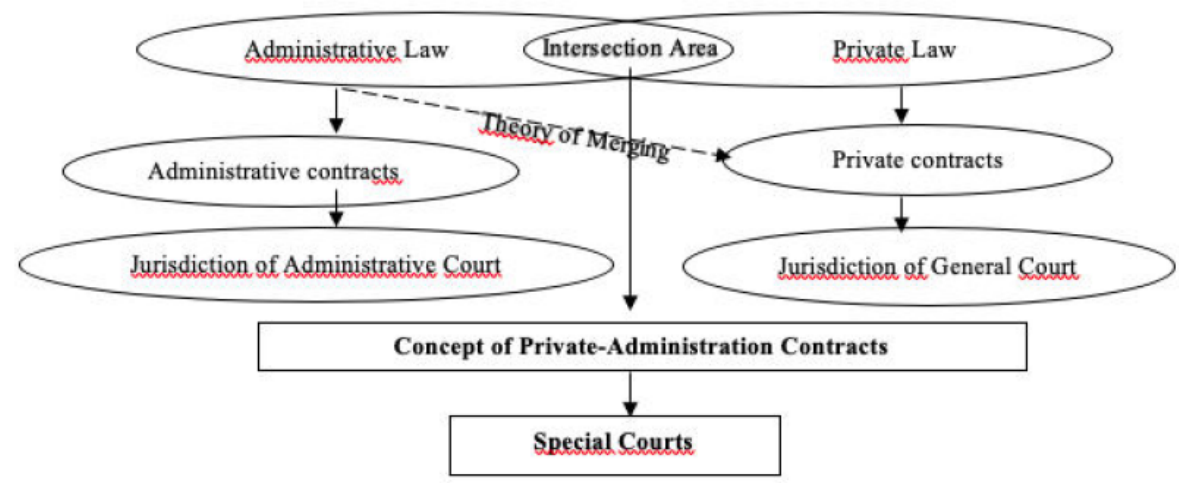

Figure 2: The Concept of Private-Administration Contracts. 
Completion of contracts in the Government procurement of goods and services is not always completed using purely civil aspects (Sujoko, 2020). For example, in the case of completion of work that has been done by the provider but has not been paid and there is no contract. The resolution for the settlement of such cases is usually carried out by an audit process and after that, a debt contract is made to pay for the work. The settlement process of such cases does not follow the principle of freedom of contract, but the flexibility of the form of administrative improvements in Law Number 30 of 2014 concerning Government Administration. In association with the sanctions due to provisions in the contract such as blacklist sanctions. In a matter that the provider requests the revocation of a blacklist, the revocation shall be submitted to the State Administrative Court (PTUN) (Mudjisantosa, 2019).

Contracts in the Government procurement of goods and services are not only seen from the pre-contract when the contract is signed, and the contract implementation/end of the contract, but it is seen from the pre-contract, contract signing, contract implementation/end of the contract and post-contract implementation or after the contract is fully done (Sujoko, 2020). This perspective will be different from the government procurement of goods and services contract which is only seen until the implementation of the contract. In its practice, after the implementation of the contract, many cases of Government procurement of goods and services contracts have been found to have state losses which the solution of the issue does not base on civil law, but it can be done with administrative law. Post-contract implementation needs to be accommodated regarding Government procurement of goods and services contracts. From several contractual practices in the Government procurement of goods and services, several contract clauses are unilateral protecting the government. For example, a clause if it is based on audit/evidence and found that there is an overpayment, then the provider is willing to deposit the overpayment to the State Treasury/Regional Treasury. In the field of construction works, some clauses are still overburdened and become the responsibility of the provider, even though the contract implementation has been completed. This clause can be found in the contractual responsibility of the provider regarding the failure of the building.

A commercial contract by the government applies the principles and norms of public law as based on the perspective of Yohanes Sogar Simamora (2009). The aspect of public law in Government procurement of goods and services contracts is administrative law. The nature of administrative law is a law related to the governmental authority (Suhariyanto, 2018). In its practice, the resolution of contractual problems uses governmental authority, such as granting an opportunity to complete a contract. Allowing completing the contract based on Presidential Regulation No. 16 of 2018 is the authority of the Commitment-making Officer (Mudjisantosa, 2018). The concept of PrivateAdministration Contracts is known as "authority, rights, and obligations" in contracts and it is not limited to "rights and obligations" as in private contracts.

The solution of the issue in the Government procurement of goods and services contracts in the Concept of Private-Administration Contracts. The first, the substance of the problem. The root of the problem in the Government procurement of goods and services contracts are seen from the administrative, technical, and legal aspects. Administrative aspects are related to the elements of administrative completeness, authority, and public legal norms in the contract because one of the parties is the government. Technical aspects related to the technical work in the contract. Legal aspects related to the implementation of rights and obligations in the contract. Second, direction or settlement jurisdiction. Dispute resolution included in the contract can be done through two processes, namely the process of dispute resolution through the litigation process in the court which then develops to dispute settlement process through cooperation (cooperative) outside the court (non-litigation) (Yuniarti, 2017). The standard processes of Litigation and nonlitigation for resolving business disputes in the context of investing in the justice system in Indonesia as a standard process that can accommodate guarantees of achieving legal certainty, expediency, and justice based on Pancasila and the 1945 Constitution (Saragi, 2014). The resolution through litigation applies settlement law and administrative law, so it is different from settlement according to administrative contracts or private contracts. Problem resolution related to the existence of elements of authority, rights, and obligations of the parties as well as related to technical work in the Government procurement of goods and services contract is carried out through Special Courts. The idea of establishing a Special Court aims to meet the demands of development injustice which is increasingly complex in society (Judicial Commission, 2013). According to Djatnika (2014), administrative/technical disputes are conducted through non-adjudication while legal disputes are done 
Table 1: The Differences and Similarities in Types of Contracts in PBJP

\begin{tabular}{|c|c|c|c|c|}
\hline \multirow[t]{2}{*}{ No } & \multicolumn{3}{|c|}{ The Differences of Type of Contract in PBJP } & \multirow[t]{2}{*}{ Similarities } \\
\hline & Administrative Contract & Private Contract & Private-Administrative Contract & \\
\hline 1 & $\begin{array}{l}\text { It is seen from the pre- } \\
\text { contract when the contract is } \\
\text { signed and the } \\
\text { implementation/end of the } \\
\text { contract. }\end{array}$ & $\begin{array}{l}\text { It is seen from the pre-contract, } \\
\text { contract signing, and contract } \\
\text { implementation/end of the } \\
\text { contract. }\end{array}$ & $\begin{array}{l}\text { It is seen from the pre-contract, contract } \\
\text { signing, contract implementation/end of the } \\
\text { contract, and after the contract is fully done } \\
\text { or post-contract implementation }\end{array}$ & \multirow[t]{7}{*}{$\begin{array}{l}\text { A contract } \\
\text { between the } \\
\text { Government and } \\
\text { Provider }\end{array}$} \\
\hline 2 & Apply administrative law & Apply private law & Apply administrative and private law & \\
\hline 3 & $\begin{array}{c}\text { Jurisdiction of Administrative } \\
\text { Court }\end{array}$ & Jurisdiction of General Court & Jurisdiction of Special Court & \\
\hline 4 & $\begin{array}{l}\text { Limitations of the principle of } \\
\text { freedom of contract }\end{array}$ & $\begin{array}{l}\text { Principle of freedom of contract } \\
\text { (follow open system), even } \\
\text { though there is a limitation in its } \\
\text { practice }\end{array}$ & $\begin{array}{l}\text { Limitations of the freedom of contract are in } \\
\text { line with Pancasila and must be understood } \\
\text { as limited freedom }\end{array}$ & \\
\hline 5 & $\begin{array}{l}\text { Problem resolution using } \\
\text { administrative law }\end{array}$ & $\begin{array}{l}\text { Problem resolution using private } \\
\text { law }\end{array}$ & $\begin{array}{l}\text { Problem resolution using administrative and } \\
\text { private law }\end{array}$ & \\
\hline 6 & $\begin{array}{l}\text { Settlement through } \\
\text { administrative court }\end{array}$ & Non-litigation dispute resolution & Non-litigation dispute resolution & \\
\hline 7 & $\begin{array}{l}\text { It is known as "authority, } \\
\text { rights, and obligations" in } \\
\text { contracts }\end{array}$ & $\begin{array}{l}\text { It is known as "rights and } \\
\text { obligations" in contracts }\end{array}$ & $\begin{array}{l}\text { It is known as "authority, rights, and } \\
\text { obligations" in contracts }\end{array}$ & \\
\hline
\end{tabular}

Source: Sujoko (2020).

through court/arbitration (Government Goods/Services Procurement Policy Institute, 2019). According to Effendi (2018), although the Supreme Court through its jurisprudence has embraced oplossing theorie, but the decisions of the judges under it have not yet referred to the existing jurisprudence. According to the authors, settlement of administrative, technical and legal disputes concurrently will be more effective than the separation of administrative and technical dispute resolution from legal disputes. Settlement through nonlitigation is carried out by the provisions contained in the contract. Table 1 illustrates the differences and similarities in types of contracts in PBJP according to administrative contracts, private contracts, and PrivateAdministrative Contracts:

\section{CONCLUSION}

The development of contract resolution or settlement in the Government procurement of goods and services is not always settled using purely civil aspects. There are inconsistencies in resolving a legal problem in the Government procurement of goods and services contracts, in which private legal issues are resolved through administrative law. This is an intersection between two aspects of law namely private law and administrative law. The concept of PrivateAdministration Contracts in bridging the intersection of aspects of administrative law and aspects of private law in the Government procurement of goods and services contracts. The concept of PrivateAdministration Contracts is different from administrative contracts and private contracts.

Theoretically, this study contributes to the resolution of this problem, there are intersections between two legal aspects, namely private law and administrative law. In practical terms, this study encourages the development of government goods/service procurement contract problem-solving practices to adopt the contract problem -solving method starting to use administrative law. By using the conceptual analysis method, this paper develops new concepts in the intersection between administrative and private law. New concepts in resolving contract issues for the procurement of goods/services of the government are a comparison of the administrative contract with private contracts. The study offers the concept of PrivateAdministration Contracts in bridging the intersection of aspects of administrative law with aspects of private law in contracts for the procurement of goods/services of the government. The findings have a theoretical benefit regarding the concept of Private-Administration Contracts as it is different from administrative contracts and private contracts, so the way to resolve contractual problems has its characteristics. The concept of Private-Administration Contracts is deemed capable as a tool for the resolution of problems with the Government's procurement of goods/services 
contracts, which are seen from the time of precontracting, contract signing, and contract implementation to post-contract implementation.

\section{REFERENCE}

Arijanta, S.B. (2018). Contract Dispute Issues. Directorate of Legal Issues Handling of LKPP

Djatnika, S. S. (2014). Mitigation of Risk of Legal Disputes in Construction Work Contracts. Case Study between Marga Raya and Kartika-Abdi JO, JBT Bank and Indika Darma (Doctoral dissertation, Tarumanegara University).

Effendi, M. (2018). Peradilan Tata Usaha Negara Indonesia Suatu Pemikiran Ke Arah Perluasan Kompetensi Pasca Amandemen Kedua Undang-Undang Peradilan Tata Usaha Negara. Jurnal Hukum dan Peradilan, 3(1), 25-36. https://doi.org/10.25216/JHP.3.1.2014.25-36

Faisal, P (2018). Introduction to Legal Opinion in Procurement of Government Goods and Services.

Febrianti, T. (2019). The Relationship between State Administration Law and Civil Law. Paper presented at University of Sriwijaya.

Gamenţ-Antoniu, N., \& Zaharie, C. G. (2010). The Field Of Administrative Contracts In The Romanian Positive Law Related To The Provisions Of Art. 2 Item (1) Let. C) From Law Nr. 554/2004 Regarding The Administrative Legal Dispute. Contemporary Legal Institutions, 2(1), 40-46.

Government Goods/Services Procurement Policy Institute, (2019). Proceeding Level 9 - 10: Settlement of Government Goods/Services Procurement Contract Disputes Construction Contracts and Decision Making Process. Jakarta: Government Goods/Services Procurement Policy Institute

Government of the Republic of Indonesia. (2018). Presidential Regulation of the Republic of Indonesia Number 16 of 2018 Regarding Procurement of Government Goods/Services. .

Hardjowahono, B. S. (2013). Academic Script Draft Law on Contract Law. National Legal Development Agency of the Ministry of Law and Human Rights Republic of Indonesia.

Hernoko, A. Y. (2010). The law of the principle of proportionality agreement in commercial contracts. Kencana.

Jamilah, L. (2012). The Principle of Freedom of Contract in the Standard Agreement. Syiar Hukum, 14(1), 26-36.

Jovanovic, M. (2019). Legal Methodology \& Legal Research and Writing, pp. 1-2. Retrieved from http://www.ius.bg.ac.rs/prof/materijali/jovmio/mei/Legal\%20m ethodology $\% 20$ and $\% 20$ legal\%20research\%20and\%20writing .pdf

Judicial Commission. (2013). Special Court. Jakarta: Center for Analysis and Information Services of the Secretariat General of the Judicial Commission.

Lubis, A. S., \& Kalo, S. (2013). Corruption in Government Procurement of Goods/Services Judging from Law Number 31 Year 1999 Juncto Law Number 20 Year 2001 Concerning Amendments to Law Number 31 Year 1999 Concerning Eradication of Corruption. Jurnal Mahupiki, 1(1).

Mudjisantosa, (2018). Government Contract Solutions.

Mudjisantosa, A. H. R. (2019). Contract Solution. CV. Primaprint.

Pedju, R. (2017). Politics, Islam, Islamic Trade Law, Nationalism: A Touchpoint of Competence in the General Courts (Civil) and State Administrative Courts in Absolute Competency. Potret Pemikiran, 21(1). https://doi.org/10.30984/pp.v21i1.735

Saragi, M. (2014). Litigation and non-litigation for the resolution of business disputes in the context of developing investment in Indonesia (Study of Law Enforcement Number 48 of 2009 concerning Judicial Power in conjunction with Law Number 30 of 1999 concerning Arbitration and Alternatives. E-Journal Graduate Unpar, 1(2), 54-73.

Seif, M. G. (2011). The administrative contract.

Simamora, Y. S. (2009). Legal agreement: legal principle of contract for the procurement of goods and services by the government. Laks Bang

Suhariyanto, B. (2018). Persinggungan kewenangan mengadili penyalahgunaan diskresi antara pengadilan tun dan pengadilan tipikor/interception of justice authority of discretion abuse between administration court and corruption courts. Jurnal Hukum dan Peradilan, 7(2), 213-236. https://doi.org/10.25216/JHP.7.2.2018.213-236

Sujoko, A. (2019). Perspectives of Corruption in Procurement of Government Goods/Services. CV. Primaprint.

Sujoko, A. (2020). Asas Kebebasan Berkontrak Dalam Pemberian Kesempatan Penyelesaian Pekerjaan Pengadaan Barang/Jasa Pemerintah (Pbjp). Masalah-Masalah Hukum, 49(2), 136-147. https://doi.org/10.14710/mmh.49.2.2020.136-147

Suparman, E., \& Atmasasmita, H. R. (2014). Legal Aspects of Government Goods/Services Procurement.

Yuniarti, R. (2016). Efisiensi Pemilihan Alternatif Penyelesaian Sengketa dalam Penyelesaian Sengketa Waralaba. Fiat Justisia, 10(3), 551-568. https://doi.org/10.25041/fiatjustisia.v10no3.793

Received on 12-01-2021

https://doi.org/10.6000/1929-4409.2021.10.77

(c) 2021 Solechan et al.; Licensee Lifescience Global.

This is an open access article licensed under the terms of the Creative Commons Attribution Non-Commercial License (http://creativecommons.org/licenses/by-nc/3.0/) which permits unrestricted, non-commercial use, distribution and reproduction in any medium, provided the work is properly cited. 